Article

\title{
Removal of Antimony in Wastewater by Antimony Tolerant Sulfate-Reducing Bacteria Isolated from Municipal Sludge
}

\author{
He Li ${ }^{1,2,3,+}$, Yue Fei ${ }^{1,2,3,+}$, Shuwen Xue ${ }^{1,3}{ }^{\oplus}$, Gege Zhang ${ }^{1,2,3}$, Ziqi Bian ${ }^{1,2,3}$, Fanfan Guo ${ }^{1,2,3}$, Li Wang ${ }^{1,2,3}$, \\ Ruiqing Chai ${ }^{1,2,3}$, Shuqi Zhang ${ }^{1,2,3}$, Zhenyu Cui ${ }^{1,2,3}$, Shiwei Wang $1,3, * \mathbb{D}$ and Jun Zhang ${ }^{1,2,3, * \mathbb{C}}$
}

1 College of Life Sciences, Northwest University, Xi'an 710069, China; lihe@stumail.nwu.edu.cn (H.L.); m18291802944@163.com (Y.F.); xuesw@nwu.edu.cn (S.X.); 202032708@stumail.nwu.edu.cn (G.Z.); bianziqi@stumail.nwn.edu.cn (Z.B.); guofanfan@stumail.nwu.edu.cnm (F.G.); wangli@stumail.nwu.edu.cn (L.W.); 2019113110@stumail.nwu.edu.cn (R.C.); 2018113050@stumail.nwu.edu.cn (S.Z.); cuizhenyu@stumail.nwu.edu.cn (Z.C.)

2 Shaanxi Key Laboratory of Animal Conservation, College of Life Sciences, Northwest University, Xi'an 710069, China

3 Key Laboratory of Resources Biology and Biotechnology in Western China, Ministry of Education, Northwest University, Xi'an 710069, China

* Correspondence: wangsw@nwu.edu.cn (S.W.); zhangjun@nwu.edu.cn (J.Z.)

+ These authors contributed equally as first author.

check for updates

Citation: Li, H.; Fei, Y.; Xue, S. Zhang, G.; Bian, Z.; Guo, F.; Wang, L.; Chai, R.; Zhang, S.; Cui, Z.; et al. Removal of Antimony in Wastewater by Antimony Tolerant SulfateReducing Bacteria Isolated from Municipal Sludge. Int. J. Mol. Sci. 2022, 23, 1594. https://doi.org/ 10.3390/ijms23031594

Academic Editor: Giovanni Musci

Received: 25 December 2021

Accepted: 25 January 2022

Published: 29 January 2022

Publisher's Note: MDPI stays neutral with regard to jurisdictional claims in published maps and institutional affiliations.

Copyright: (C) 2022 by the authors. Licensee MDPI, Basel, Switzerland. This article is an open access article distributed under the terms and conditions of the Creative Commons Attribution (CC BY) license (https:// creativecommons.org/licenses/by/ $4.0 /)$

\begin{abstract}
Antimony (Sb), a global and priority controlled pollutant, causes severe environmental issues. Bioremediation by microbial communities containing sulfate-reducing bacteria (SRB) is considered to be among the safest, economical, and environmentally friendly methods to remove $\mathrm{Sb}$ from wastewater. However, the roles of SRB species in these communities remain uncertain, and pure cultures of bacteria that may be highly efficient have not yet been developed for $\mathrm{Sb}$ removal. In this study, an $\mathrm{Sb}$ tolerant community was enriched from municipal sludge, and molecular ecological analysis showed that Escherichia (40\%) and Desulfovibrio (15\%) were the dominant bacteria. Further isolation and identification showed that the enriched SRB strains were closely related to Cupidesulfovibrio oxamicus, based on the molecular analyses of $16 \mathrm{~S}$ rRNA and dsrB genes. Among them, a strain named SRB49 exhibited the highest activity in removal of $\mathrm{Sb}(\mathrm{V})$. SRB49 was able to remove $95 \%$ of $\mathrm{Sb}(\mathrm{V})$ at a concentration of $100 \mathrm{mg} / \mathrm{L}$ within $48 \mathrm{~h}$ under optimum conditions: a temperature of $37-40^{\circ} \mathrm{C}$, an initial $\mathrm{pH}$ value of $8,4 \mathrm{mM}$ of sulfate, and an initial redox potential of $145-229 \mathrm{mV}$. SEM-EDX analysis showed that SRB49 did not adsorb $\mathrm{Sb}(\mathrm{V})$ but reduced and precipitated $\mathrm{Sb}(\mathrm{V})$ via the formation of $\mathrm{Sb}_{2} \mathrm{~S}_{3}$. The results demonstrated the potential roles that pure cultures of SRB species may play in $\mathrm{Sb}$ removal and the use of $\mathrm{Sb}$-tolerant SRB strains for Sb remediation.
\end{abstract}

Keywords: antimony tolerant; sulfate-reducing bacterial strains; antimony removal

\section{Introduction}

Antimony ( $\mathrm{Sb}$ ) is a metalloid widely used in various industrial fields, such as in the production of flame retardants, batteries, plastics, and catalysts [1]. With rapidly increasing use, $\mathrm{Sb}$ is currently the ninth most mined metal in the world [2]. Due to natural processes and human activities such as mining and smelting, coal combustion, waste incineration, and spent ammunition, severe $\mathrm{Sb}$ pollution is emerging worldwide, especially in China, which has the richest antimony ore resources and the highest mining activity [2,3]. Wastewaters from mines and smelting factories containing high levels of $\mathrm{Sb}(\mathrm{V})$ are major pollution sources that threaten the ecosystems of the receiving waters as well as human health through drinking water and the food chain [4]. Due to its toxicity, being a suspected carcinogen, and its adverse effects on ecosystems [5], Sb and its compounds are considered as priority pollutants by the United States Environmental Protection Agency and the European Union [1]. Therefore, treatments for Sb pollution have become a research focus worldwide over the last decade $[1,4,6]$. 
As compared to various physical and chemical methods, such as coagulation, electrodeposition, adsorption, and ionic exchange, bioremediation methods are more cost effective with less process complexity and secondary pollution [7]. Through biosorption, oxidation, reduction, and/or methylation, microorganisms play an important role in the mitigation of $\mathrm{Sb}$ contamination. Metal sulfide precipitation by sulfate-reducing bacteria (SRB) has potential as a method for removing $\mathrm{Sb}$ from water [8]. Sb mainly has two oxidation states in an aqueous environment, with $\mathrm{Sb}(\mathrm{V})$ and $\mathrm{Sb}(\mathrm{III})$ as the predominant species in oxic and anoxic settings, respectively [8]. Under anaerobic conditions, $\mathrm{H}_{2} \mathrm{~S}$ produced through the sulfate reduction of $\mathrm{SRB}$ can reduce $\mathrm{Sb}(\mathrm{V})$ to $\mathrm{Sb}(\mathrm{III})$, coupled with the subsequent formation of $\mathrm{Sb}$ (III) precipitate $\mathrm{Sb}_{2} \mathrm{~S}_{3}$ (stibnite), which decreases $\mathrm{Sb}$ mobility and its threat to drinking water $[9,10]$.

Several studies have been reported in recent years regarding bioreduction by SRB flora in various anaerobic environments $[7,8,11,12]$. The bacterial communities in SRB enriched cultures were reported to remove $83.5-90 \%$ of $\mathrm{Sb}(\mathrm{V})$ at $2.5-50 \mathrm{mg} / \mathrm{L}$ but only $48.1 \%$ at $75 \mathrm{mg} / \mathrm{L}$ [13]. The presence of $100-200 \mathrm{mg} / \mathrm{L}$ Fe(II) [7] or $4 \mathrm{mM}$ sulfate [8] enhanced the Sb removal efficiency of SRB flora. Although the Sb concentration in the sediment of rivers polluted by antimony ore can be as high as $17,000 \mathrm{mg} / \mathrm{kg}$ [14], there has been a paucity of reports detailing the treatment of high $\mathrm{Sb}$ concentrations in wastewater, which may be due to the toxicity of $\mathrm{Sb}$ to bacteria [15].

The aforementioned studies were based on the activity of SRB enriched cultures with complex bacterial community structures. Although SRB species were originally thought to be the major functional group responsible for the reduction and precipitation of $\mathrm{Sb}(\mathrm{V})$, the roles of the SRB species in these communities have remained uncertain as a highly efficient pure culture of SRB had yet to be developed for $\mathrm{Sb}$ removal. However, when a pure culture strain of SRB, Desulfovibrio vulgaris DP4, was reported to have no $\mathrm{Sb}(\mathrm{V})$ removal ability when incubated with $2 \mathrm{mM} \mathrm{Sb}(\mathrm{V})$, that understanding could not be supported [12]. Moreover, instead of precipitating $\mathrm{Sb}$ and reducing the mobility of $\mathrm{Sb}$, Desulfovibrio vulgaris DP4 was reported to increase the mobility of $\mathrm{Sb}(\mathrm{V})$ adsorbed by goethite combined with generating thioantimonate [16]. SRB species such as Desulfovibrio spp. and Desulfomicrobium spp. have been found in surprisingly low proportions $(<1 \%)$ in the bacterial community of $\mathrm{SRB}$ enriched cultures and in an $\mathrm{Sb}$ polluted environment $[7,8,12]$. These results suggested that the roles of these SRB species in antimony mobility need to be further investigated. In addition, environmental factors, including initial $\mathrm{pH}$, temperature, redox potential, sulfate concentration, co-contamination of heavy metal ions, and the existence of $\mathrm{Fe}^{0}$, influence the treatment efficiency of Sb contaminated wastewaters by SRB species, but they have rarely studied or analyzed.

To the best of our knowledge, no study concerning the precipitation and the removal of $\mathrm{Sb}(\mathrm{V})$ from wastewater has been conducted based on the activity of a pure culture of SRB, and no strains of antimony resistant SRB have been reported. In addition, the environmental parameters influencing the $S b(V)$ treatment efficiency of SRB have not been examined in a pure culture system. In this study, we enriched and isolated Sb resistant SRB strains from a municipal sewerage, refined the treatment parameters to remove $\mathrm{Sb}(\mathrm{V})$ from wastewater, and analyzed the mechanisms of $\mathrm{Sb}(\mathrm{V})$ removal.

\section{Results}

\subsection{Enrichment of $S R B$ Community with $S b(V)$ Removal Activity and Its Community Analysis}

To obtain a highly $\mathrm{Sb}$ tolerant bacterial community, a 14-day incubation of municipal sludge with a high concentration of $\mathrm{Sb}(\mathrm{V})$ was performed. The results showed that the municipal sludge reduced $90 \%$ of $\mathrm{Sb}(\mathrm{V})$, while no reduction of total $\mathrm{Sb}$ was observed in the control group with only $\mathrm{Sb}(\mathrm{V})$ and $\mathrm{ddH}_{2} \mathrm{O}$ (Figure 1a), indicating that the $\mathrm{Sb}(\mathrm{V})$ was stable. After SRB enrichment, the $\mathrm{Sb}$ removal efficiency of the enriched community increased to $96 \%$ within $48 \mathrm{~h}$. The illumina sequencing of the $16 \mathrm{~S}$ rRNA gene of the SRB enriched community obtained a total of 48,303 sequences and identified 219 operational taxonomic units (OTUs) at a $97 \%$ sequence similarity cutoff. The Simpson and Shannon diversity 
indices were 0.32 and 2.95, respectively. The relative abundance at the genus and phylum levels are shown in Figure 1b,c. The bacterial community at the level of phylum was mainly composed of Proteobacteria (57.3\%), Firmicutes (21.1\%), and Bacteroidetes (16.6\%). More than $84 \%$ of the OTUs were identified at the genus level, and the most dominant genera in the SRB enriched culture were Escherichia (40.2\%) followed by Desulfovibrio $(15.0 \%)$. The less abundant genera included Clostridium sensu stricto $(7.6 \%)$, Bacteroides (3.4\%), Dysgonomonas (3.3\%), Macellibacteroides (2.9\%), Parabacteroides (2.3\%), Cloacibacillus $(2.2 \%)$, and Clostridium_XlVb (1.9\%) (Figure 1c).

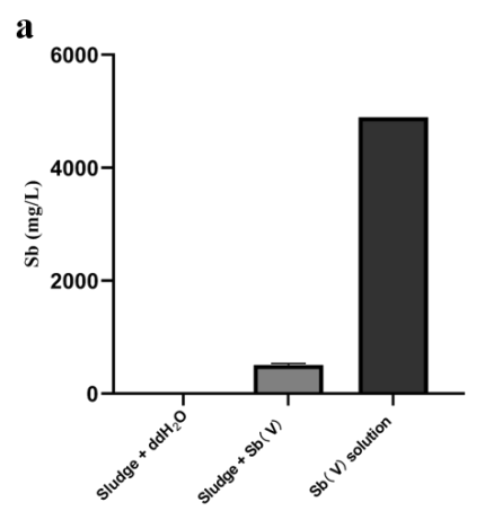

\section{b}
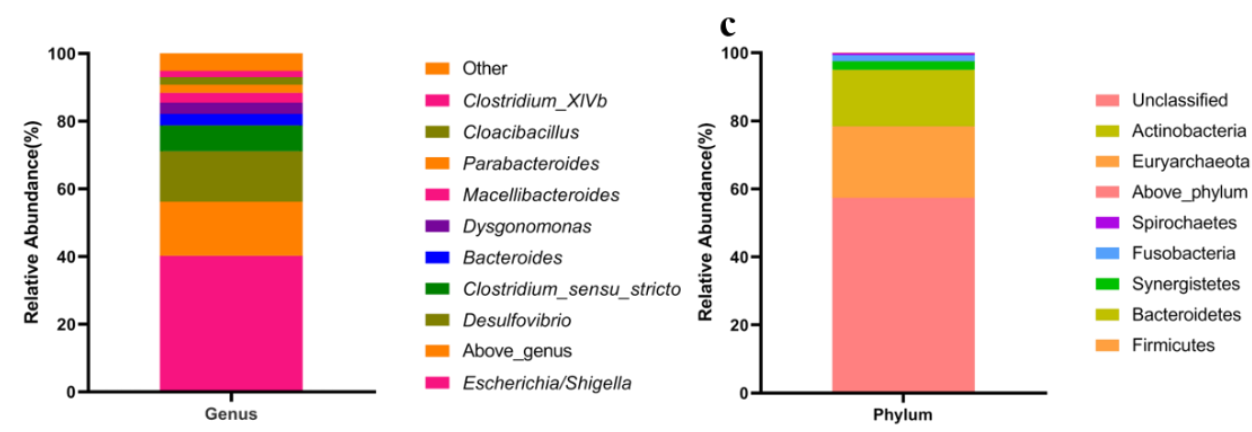

Figure 1. The removal of $\mathrm{Sb}$ in municipal sludge after 14-day incubation (a) and the community composition of SRB enriched community at the genus (b) and phylum levels (c).

\subsection{Isolation and Identification of Sb Tolerant SRB Strains}

Four strains were isolated and named SRB311, SRB31315, SRB31316, and SRB49. All the strains were Gram negative, non spore forming, vibrio shaped bacteria with a size of $3 \pm 0.8 \mu \mathrm{m} \times 0.4 \pm 0.03 \mu \mathrm{m}$ (Figure $2 \mathrm{a}-\mathrm{c}$ ).
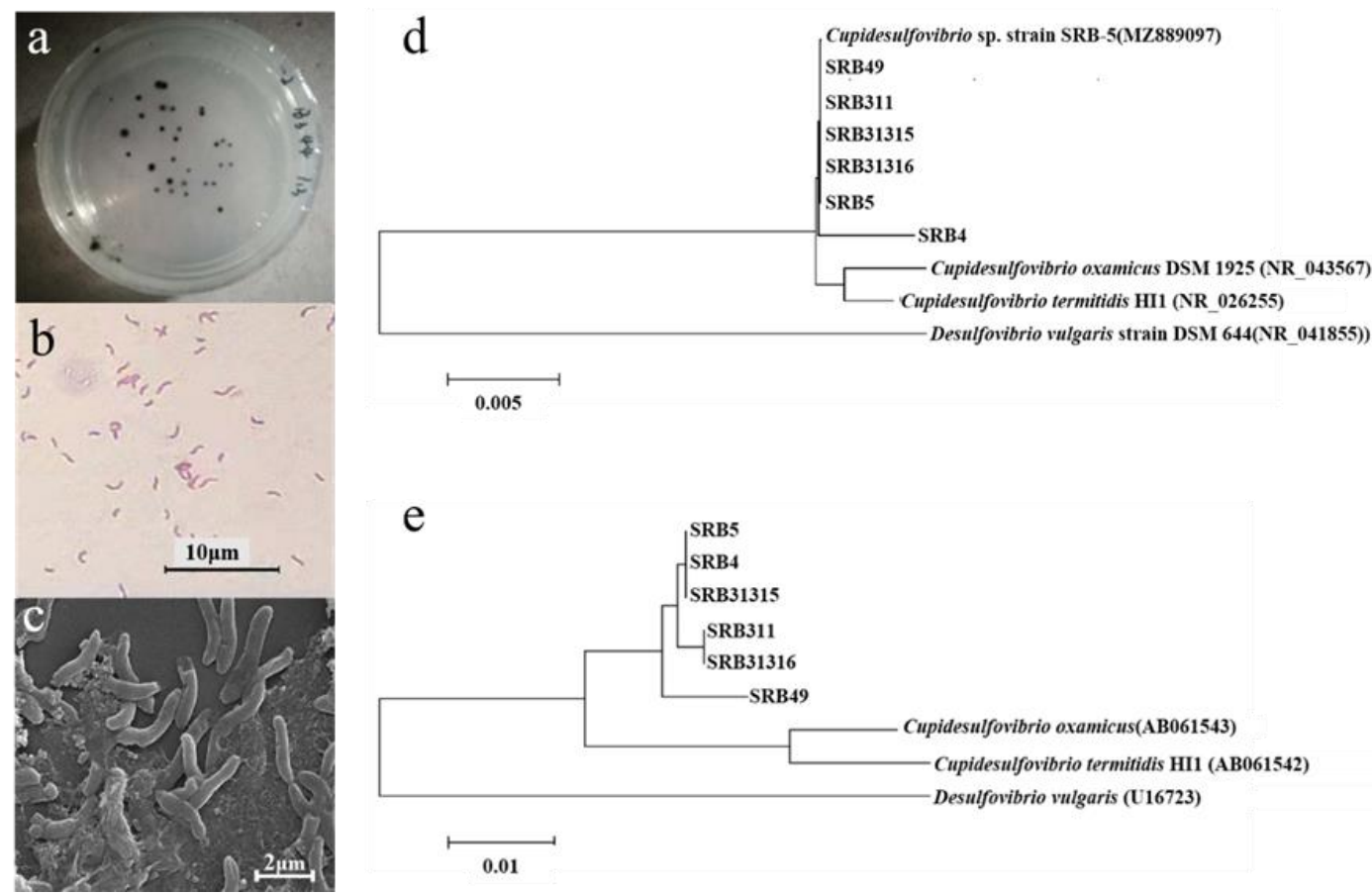

Figure 2. Morphology of SRB isolates on the plate (a), under optical microscope (b), and scanning electron microscopes (c). Phylogenetic tree of all SRB strains based on 1.4 Kb of 16S rRNA gene (d) and $300 \mathrm{bp}$ of $d s r B$ gene (e) sequence analysis. 
Based on the analysis of $1.4 \mathrm{~kb}$ of the $16 \mathrm{~S}$ rRNA gene sequence, all the strains shared a $100 \%$ sequence similarity to each other and were closely related to the Cupidesulfovibrio strains, a genus recently separated from genus Desulfovibrio. The most closely related strains were C. oxamicus and C. termitidis, with sequence similarities of $99.5 \%$ and $98.3 \%$, respectively (Figure $2 \mathrm{~d}$ ). To further distinguish the strains, the sequences of the $d s r B$ gene were analyzed and all strains were classified to the three clusters (Figure 2e) closest related to C. oxamicus and C. termitidis. SRB49 was closest related to C. oxamicus and C. termitidis, with a sequence similarity of $97.4 \%$ and $97.1 \%$, respectively. SRB311 and SRB31316 had the same $d s r B$ sequences and were the closest related to C. oxamicus ( $97.7 \%$ similarity) and C. termitidis (97.4\% similarity) (Figure $2 \mathrm{e}$ ). Therefore, the four strains were identified as C. oxamicus.

\section{3. $S b(V)$ Removal by Pure Culture of SRB Strains}

All SRB strains exhibited the ability to remove Sb from synthetic wastewater, and SRB4, SRB5, and SRB49 (44-47.2\%) had significantly higher Sb-removal efficiency, as compared to other strains (22-29.3\%) within $24 \mathrm{~h}$ (Figure 3a). SRB49 showed the highest Sb(V)-removal efficiency and thus was selected for the following experiments.

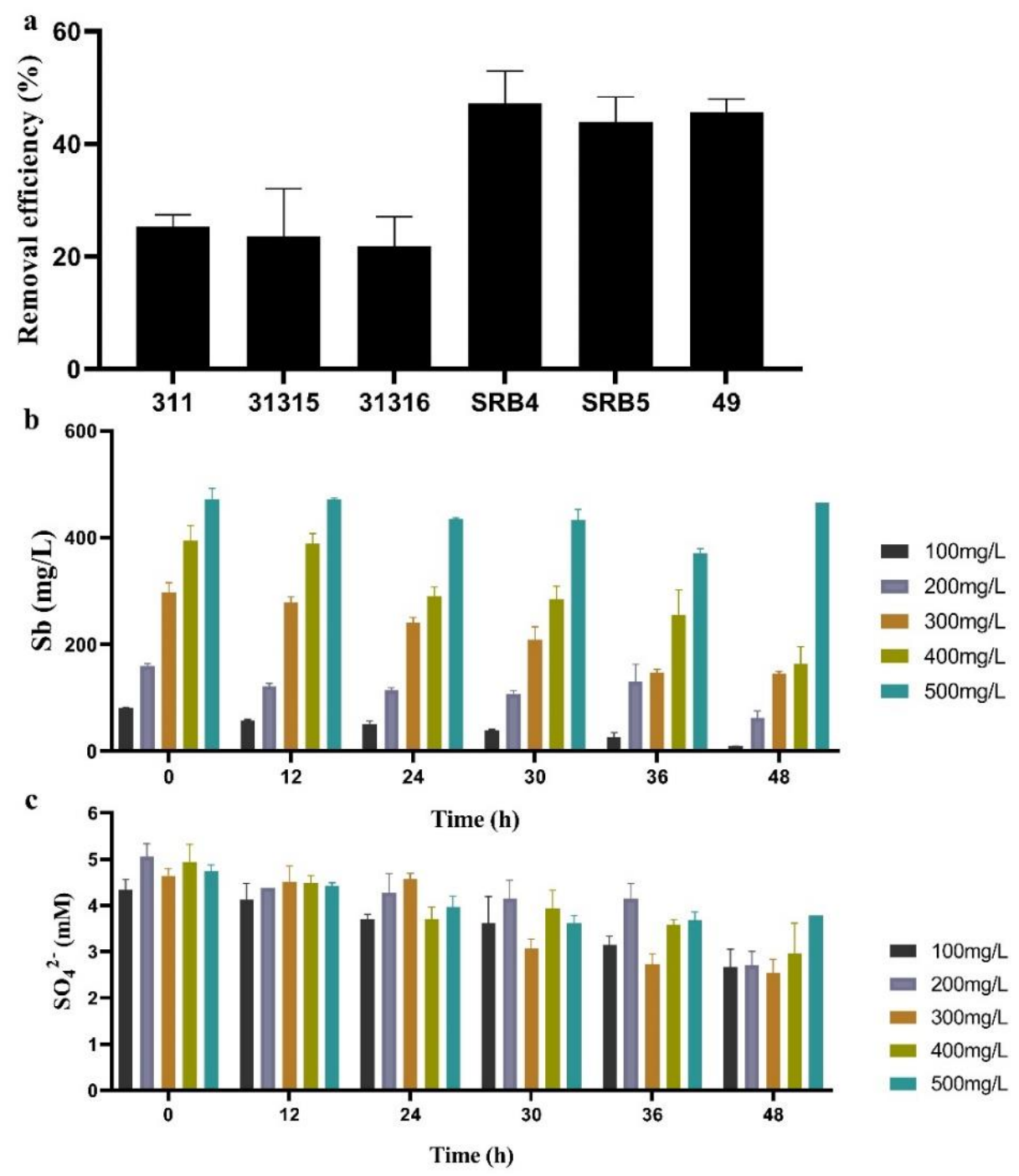

Figure 3. The Sb-removal efficiency of all SRB strains within $24 \mathrm{~h}$ (a), the performance of SRB49 on Sb removal (b) and sulfate consumption (c) within $48 \mathrm{~h}$ in different $\mathrm{Sb}(\mathrm{V})$ concentrations. 
For the analysis of $\mathrm{Sb}(\mathrm{V})$ tolerance and removal efficiency by SRB49 at higher $\mathrm{Sb}$ concentrations, SRB49 was incubated in synthetic wastewater with $\mathrm{Sb}(\mathrm{V})$ concentrations of $100-500 \mathrm{mg} / \mathrm{L}$ for $48 \mathrm{~h}$ (Figure $3 \mathrm{~b}$ ). SRB49 exhibited a high activity of $90.8 \%$ removal efficiency against $100 \mathrm{mg} / \mathrm{L}$ of $\mathrm{Sb}(\mathrm{V})$. At higher $\mathrm{Sb}(\mathrm{V})$ concentrations of 200, 300, and $400 \mathrm{mg} / \mathrm{L}$, the final removal of $\mathrm{Sb}$ was reduced to $60 \%, 51 \%$, and $58 \%$, respectively, which indicated that the activity of SRB49 in this treatment was partially inhibited (Figure $3 b$ ). The sulfate consumptions were not significantly different among treatments in $\mathrm{Sb}(\mathrm{V})$ concentrations of 100-400 $\mathrm{mg} / \mathrm{L}$ (Figure 3c), suggesting that the growth of SRB49 was not affected by $\mathrm{Sb}(\mathrm{V})$ concentrations of up to $400 \mathrm{mg} / \mathrm{L}$. At an $\mathrm{Sb}$ concentration of $500 \mathrm{mg} / \mathrm{L}$, SRB49 showed no sulfate consumption within $48 \mathrm{~h}$. This result indicated that the growth and $\mathrm{Sb}(\mathrm{V})$ removal ability of SRB 49 was thoroughly inhibited by $500 \mathrm{mg} / \mathrm{L}$ of $\mathrm{Sb}(\mathrm{V})$.

\subsection{Effects of Different Culture Parameters on $S b(V)$ Removal by SRB49}

\subsubsection{Effect of Redox Potential on the Removal of $\mathrm{Sb}(\mathrm{V})$}

The redox potential in the synthetic wastewater without bacteria decreased from 229 to $145 \mathrm{mV}$ with the decreased volume of upper air, and treatment with $0 \mathrm{~mL}$ upper air plus an $\mathrm{N}_{2}$ flush and deoxidizer further reduced the initial Eh to $95 \mathrm{mV}$ (Figure 4). After incubation with SRB49 for $48 \mathrm{~h}$, the Eh value turned negative and sharply decreased from -78.3 to $-327 \mathrm{mV}$ with the volume decrease in the upper air (Figure 4). This supported a previous report that had suggested that the growth in SRB had resulted in a strong reduction in the culture [13]. No significant differences were observed in $\mathrm{Sb}(\mathrm{V})$ removal efficiency (89.9-90.2\%) or sulfate consumption $(2 \mathrm{mM})$ among treatments with different upper air (Figure $5 \mathrm{a}, \mathrm{b}$ ). On the contrary, in the treatment using $0 \mathrm{~mL}$ upper air plus $\mathrm{N}_{2}$ flush and deoxidizer, neither $\mathrm{Sb}(\mathrm{V})$ removal nor sulfate consumption was observed (Figure $5 \mathrm{a}, \mathrm{b}$ ). The Eh value was still positive, with only a slightly decrease. This result indicated that the initial Eh of 229-145 mV was suitable for SRB49 growth and Eh $<95 \mathrm{mV}$ thoroughly inhibited the growth of SRB49. Therefore, $0 \mathrm{~mL}$ upper air (initial Eh of $145 \mathrm{mV}$ ) were used for the following experiments.

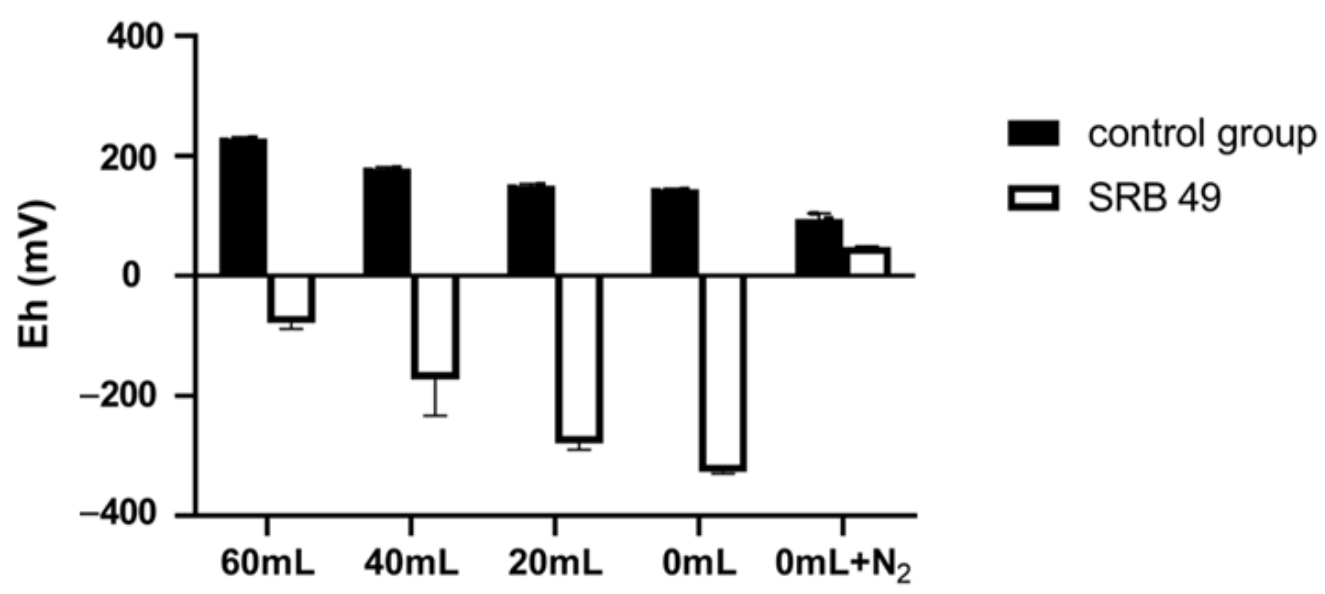

Figure 4. The redox potential in the synthetic wastewater with different upper air after incubated with and without SRB49 for $48 \mathrm{~h}$. 

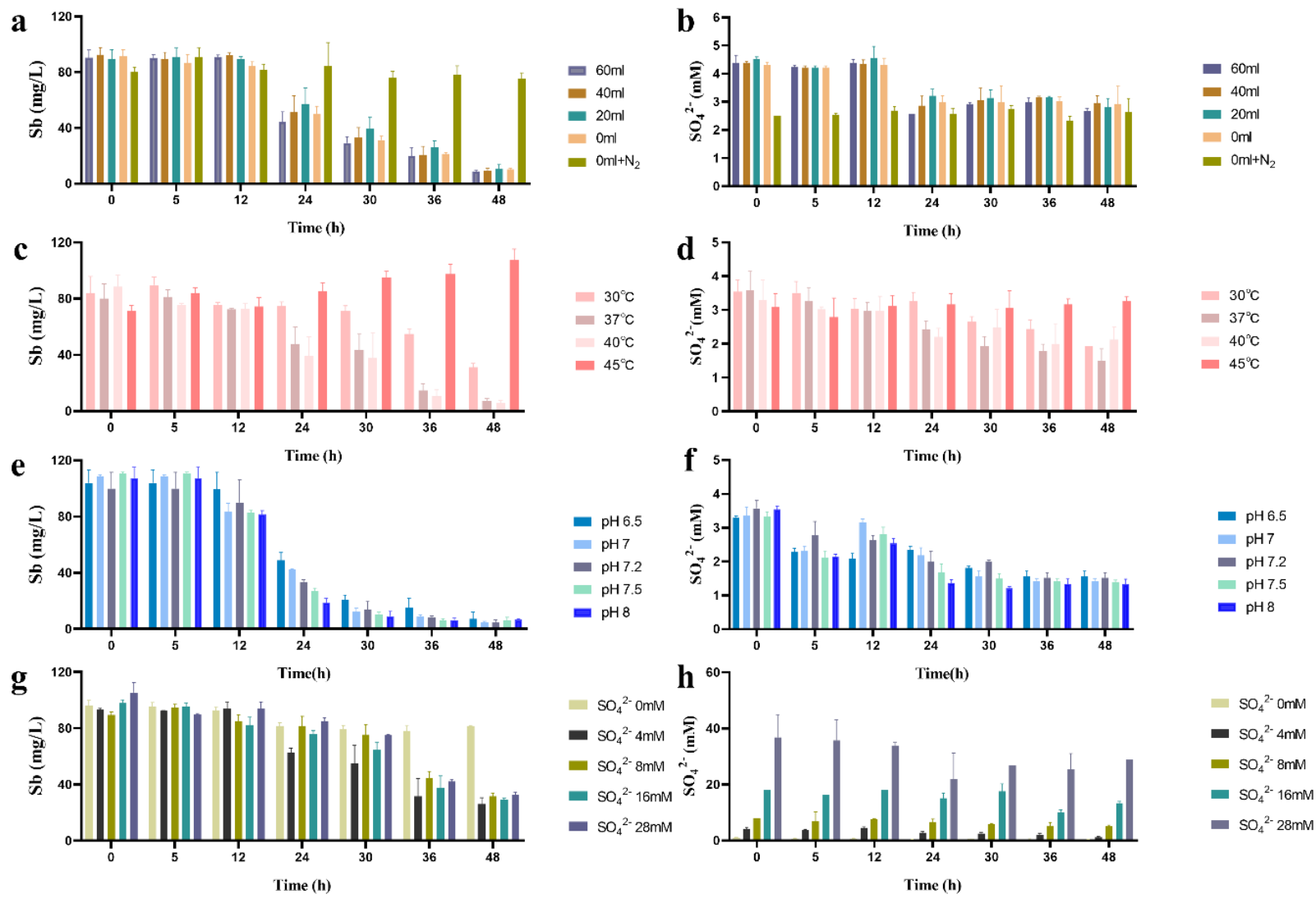

Figure 5. Sb-removal $(\mathbf{a}, \mathbf{c}, \mathbf{e}, \mathbf{g})$ and sulfate consumption $(\mathbf{b}, \mathbf{d}, \mathbf{f}, \mathbf{h})$ by SRB49 under different culture parameters.

2.4.2. Effect of Temperature, Initial $\mathrm{pH}$, and Sulfate Concentration on the Removal of $\mathrm{Sb}(\mathrm{V})$

The effect of temperature, initial $\mathrm{pH}$, and sulfate concentration on the batch treatment of $\mathrm{Sb}(\mathrm{V})$ by $\mathrm{SRB} 49$ was examined within a temperature range of $30-45^{\circ} \mathrm{C}$, $\mathrm{pH}$ values of $6.5-8$, and sulfate concentrations of 2-28 mM, respectively. After a 48 -h incubation, more than $90 \%$ of the aqueous $\mathrm{Sb}$ was removed between the temperature range of $37-40{ }^{\circ} \mathrm{C}$ (Figure $5 \mathrm{c}$ ), while only $59.4 \%$ of the aqueous $\mathrm{Sb}$ was removed at $30^{\circ} \mathrm{C}$. The sulfate consumption at $30^{\circ} \mathrm{C}$ was $0 \mathrm{mM}$ within the first $24 \mathrm{~h}$ and then reached the same value as treatments at $37^{\circ} \mathrm{C}$ and $40^{\circ} \mathrm{C}$ within $48 \mathrm{~h}$ (Figure $5 \mathrm{~d}$ ), which indicated the reduction in Sb-removal efficiency was due to the delayed growth in SRB49 at temperatures $\leq 30^{\circ} \mathrm{C}$. No removal of $\mathrm{Sb}$ and sulfate consumption was observed in the treatment at $45^{\circ} \mathrm{C}$, indicating that the growth of SRB49 strain was thoroughly inhibited.

After a 48 -h incubation, over $93-96 \%$ of the aqueous $\mathrm{Sb}$ was removed at the initial $\mathrm{pH}$ range of 6.5-8, and no significant differences were found among all the treatments, which indicated that SRB49 could adapt to a wide range of $\mathrm{pH}$ values. The $\mathrm{Sb}$ concentration only varied significantly among treatments within a $24-\mathrm{h}$ incubation (Figure $5 \mathrm{e}$ ). The Sb removal efficiency within $24 \mathrm{~h}$ increased from $52-82 \%$ with the increase in the initial $\mathrm{pH}$ of 6.5 to 8 , wherein a high removal rate of $3.69 \mathrm{mg} / \mathrm{L} \cdot \mathrm{h}$ was reached. The sulfate consumption ranged from 1.74 to $2.21 \mathrm{mM}$ (Figure $5 \mathrm{f}$ ). Taken together, these results showed that SRB49 could exhibit high $\mathrm{Sb}$-removal activity across a wide range of $\mathrm{pH}$ values and the different initial $\mathrm{pH}$ values affected the rate of antimony removal.

After a 48-h incubation, 89.8-90.3\% of the aqueous $\mathrm{Sb}$ was removed over an initial sulfate concentration of 4-28 mM (Figure $5 \mathrm{~g}$ ). No significant difference in $\mathrm{Sb}$ removal and sulfate consumption were found among all the treatments, which indicated that SRB49 could adapt to high sulfate concentrations (Figure $5 \mathrm{~h}$ ). The treatment without sulfate showed no Sb removal (Figure $5 \mathrm{~g}, \mathrm{~h}$ ). Within the first $24 \mathrm{~h}$, the $\mathrm{Sb}$ removal was 50.9\% in a 
treatment with $4 \mathrm{mM}$ of sulfate, which was significantly higher than that of other groups $(18-20 \%)$, suggesting that the Sb removal was faster at $4 \mathrm{mM}$ sulfate within the first $24 \mathrm{~h}$.

\subsection{SEM-EDX Characterization Analysis}

The precipitates after incubation with SRB49 for $48 \mathrm{~h}$ were characterized by scanning electron microscopy-energy dispersive X-ray (SEM-EDX) (Figure 6). The SRB bacteria were entangled with amorphous precipitates that were typically less than $1 \mu \mathrm{m}$ in diameter (Figure 6a,c). The energy dispersive X-ray (EDX) analysis on the surface of the bacteria showed that there was no Sb element on the bacterial surface (Figure $6 a, b$ ), suggesting that the bacteria did not absorb any Sb. EDX analysis of the precipitates of SRB49 detected the $\mathrm{Sb}$ and $\mathrm{S}$ peaks and found that the ratio of $\mathrm{Sb} / \mathrm{S}$ was approximately 2:3 (Figure $6 \mathrm{c}, \mathrm{d}$ ), which indicated the formation of $\mathrm{Sb}_{2} \mathrm{~S}_{3}$.
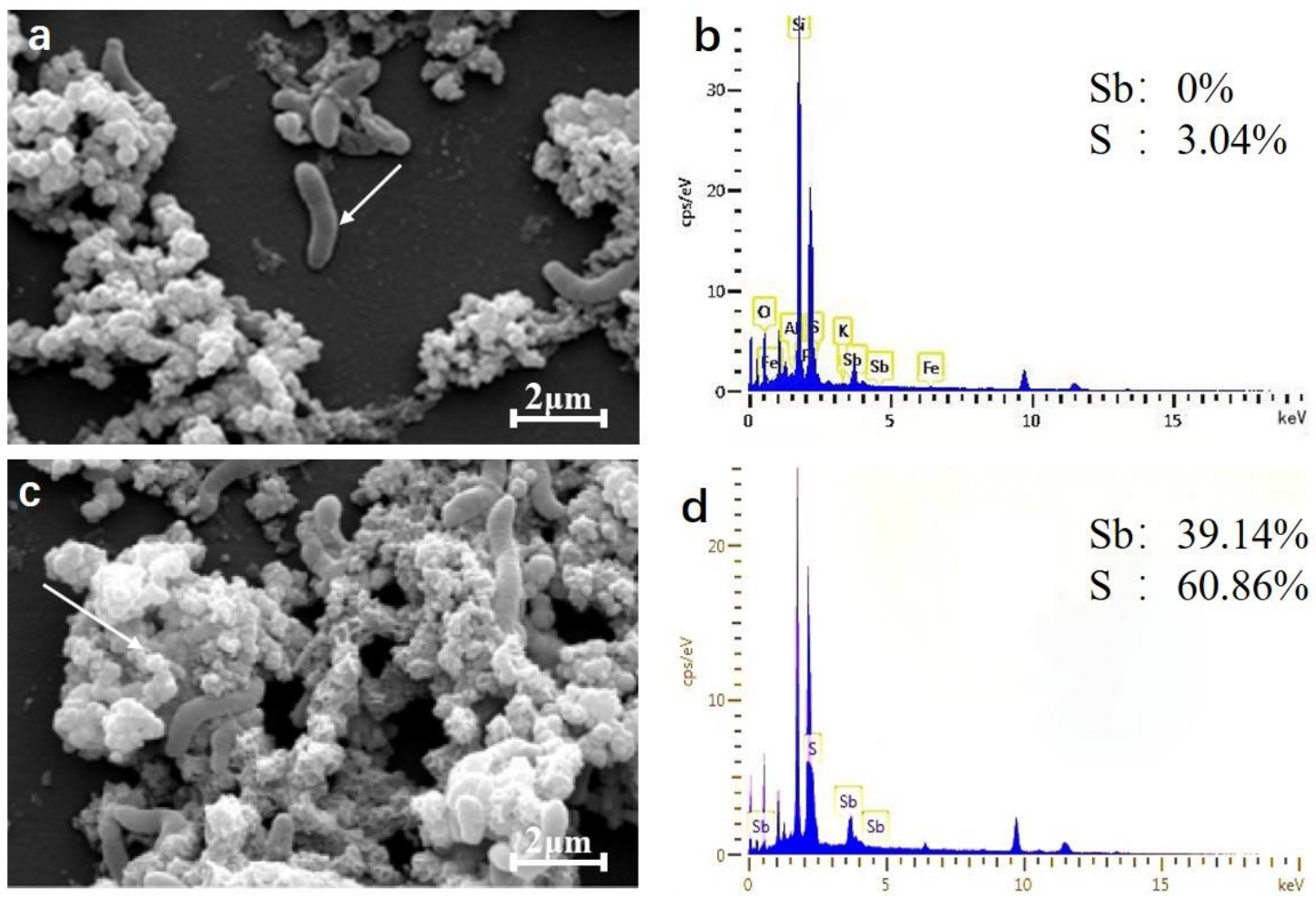

Figure 6. Scanning electron micrographs of cells (a) and mineral precipitates (c) and EDX spectrum on the cell surface (b) and mineral precipitates (d) shown by white arrows.

\section{Discussion}

\subsection{Community Analysis of SRB Community Enrichment Culture}

After enrichment, the SRB community was dominated by a phylum of Proteobacteria (57.3\%), Firmicutes (21.1\%), and Bacteroidetes (16.6\%). They were ubiquitously found in various anaerobic sludge and SRB enriched cultures for $\mathrm{Sb}(\mathrm{V})$ bioreduction $[7,8]$. These results were in accordance with previous reports that showed that Proteobacteria was overwhelmingly dominant [8]. The most abundant genus, Escherichia, was composed of only one OTU, which accounted for $40.2 \%$ of the total. E. coli was also found as the most dominant specie in lactate fed SRB enriched cultures with Sb removal activity [7]. Its low nutrition requirements and wide distribution in various anaerobic environments make it difficult to remove when purifying and culturing SRB [7]. Genus Desulfovibrio was the second dominant genus $(15.0 \%)$ in the SRB enriched community and also the only SRB genus found in this study. The proportion of SRB was much higher in this study, as compared to that found in other reports (e.g., 0.55-1\%), which suggested that enrichment by incubation with high levels of $\mathrm{Sb}(\mathrm{V})$ probably promoted the growth in $\mathrm{Sb}$ tolerant 
Desulfovibrio species and the possibility of sulfate bioreduction. Pseudomonas and Geobacter have been identified as key genera for $\mathrm{Sb}(\mathrm{V})$ bioreduction $[7,8]$ and were not detected in this study. Therefore, the SRB enriched culture showed significant differences in community composition as well as a high $\mathrm{Sb}(\mathrm{V})$ removal activity $(96 \%)$, which indicated that diverse bacteria were involved in $\mathrm{Sb}(\mathrm{V})$ bioreduction.

\subsection{Sb Removal by Sb Tolerant SRB Strains}

In this study, the SRB enriched culture and the purified SRB strains were tested for precipitates and $\mathrm{Sb}(\mathrm{V})$ removal activity from wastewater with $>90 \%$ removal efficiency in an $\mathrm{Sb}(\mathrm{V})$ concentration of $100 \mathrm{mg} / \mathrm{L}$ within $48 \mathrm{~h}$. When the $\mathrm{Sb}(\mathrm{V})$ concentration was increased to $400 \mathrm{mg} / \mathrm{L}$, SRB49 still exhibited 58\% removal efficiency. In previous experiments, SRB enriched cultures that showed high $\mathrm{Sb}$ removal efficiency were generally conducted in an $\mathrm{Sb}(\mathrm{V})$ concentration of less than $25 \mathrm{mg} / \mathrm{L}[7,9,17]$. Zhang et al. reported a removal efficiency of $83.5-90 \%$ at an $\mathrm{Sb}(\mathrm{V})$ concentration of $2.5-50 \mathrm{mg} / \mathrm{L}$ but only $48.1 \%$ at $75 \mathrm{mg} / \mathrm{L}$ of $\mathrm{Sb}(\mathrm{V})$ [13]. Moreover, SRB49 could rapidly reduce $82 \%$ of $\mathrm{Sb}(\mathrm{V})$ within $24 \mathrm{~h}$ and reach over $94.2 \%$ removal within $36 \mathrm{~h}$, with the highest removal rates, of 3.69 and $2.81 \mathrm{mg} / \mathrm{L} \cdot \mathrm{h}$, respectively. The $\mathrm{Sb}$ removal efficiency of SRB enriched culture was generally reported to reach the highest values after 3-9 days of incubation $[7,9,13,17]$. The reduction rates for pure antimonate-reducing bacteria were in the range of $0.33-2.88 \mathrm{mg} / \mathrm{L} \cdot \mathrm{h}[18,19]$. Therefore, the $\mathrm{Sb}$ tolerant strain, SRB49, used in this study exhibited a high rate of $\mathrm{Sb}$ removal in high $\mathrm{Sb}(\mathrm{V})$ concentrations within a short time. The precipitate was $\mathrm{Sb}_{2} \mathrm{~S}_{3}$ and had no adsorption of $\mathrm{Sb}$ on the surface of the SRB49, which indicated the SRB49 mainly removed $\mathrm{Sb}(\mathrm{V})$ through metal sulfide precipitation. Pure strains of SRB, D. vulgaris DP4, was reported to exhibit no $\mathrm{Sb}(\mathrm{V})$ removal ability when incubated with $2 \mathrm{mM} \mathrm{Sb}(\mathrm{V})$ [12] and increased the mobility of $\mathrm{Sb}(\mathrm{V})$ adsorbed by goethite [16]. This conflict in the role of SRB species in Sb removal may be explained by the high tolerance of $\mathrm{Sb}(\mathrm{V})$ towards $\mathrm{SRB} 49$, which could still grow in an $\mathrm{Sb}(\mathrm{V})$ concentration in excess of $2 \mathrm{mM}$ (equal to $243.5 \mathrm{mg} / \mathrm{L}$ ). To the best of our knowledge, this is the first report of $\mathrm{Sb}$ tolerant $\mathrm{SRB}$ strains with a high $\mathrm{Sb}(\mathrm{V})$ removal rate.

\subsection{Influence of Different Culture Parameters on $S b(V)$ Removal of SRB49}

SRB49 exhibited more than $90 \% \mathrm{Sb}(\mathrm{V})$ removal efficiency within a broad range of $\mathrm{pH}$ values, $6.5-8$, temperatures of $37-40^{\circ} \mathrm{C}$, sulfate concentrations of 2-28 $\mathrm{mM}$, and Eh of 145-229 $\mathrm{mV}$. The highest removal efficiency was $95.7 \%$ when the $\mathrm{pH}$ was 7 at $40{ }^{\circ} \mathrm{C}$ and in $4 \mathrm{mM}$ of sulfate. This wide adaption range of SRB49 suggested its potential application for $\mathrm{Sb}$ containment control in various environments.

SRB49 showed better growth and Sb removal under an initial Eh of 145-229 mV and no growth under an initial Eh of less than $95 \mathrm{mV}$, which indicated that the SRB49 isolated in this study was not an obligate anaerobe. SRB has been shown to be active under oxygen ranging from anaerobic to aerobic [20]. The facultative anaerobic SRB of genera Desulfotomaculum and Vibrio has been isolated from both crude oil and marine corrosive steel and exhibited corrosive functions [21,22]. Mogensen et al. [23] isolated an oxygenresistant sulfate-reducing strain of DVO5 (T) from activated sludge that could survive under $100 \%$ air oxygenation for $120 \mathrm{~h}$. Since $\mathrm{Sb}$ has been present mainly as $\mathrm{Sb}(\mathrm{V})$ under oxic conditions and remained the predominant species over a wide redox range $[13,24]$, the discovery of facultative SRB capable of $\mathrm{Sb}$ bioprecipitation would be beneficial for $\mathrm{Sb}(\mathrm{V})$ removal under wider redox ranges and helpful for understanding the biochemical roles of SRB on Sb mobility.

\section{Materials and Methods}

\subsection{Enrichment of Sb Tolerant Bacterial Community}

Municipal sludge was obtained from Ruicheng Sewage Treatment Plant in Yuncheng City, Shanxi Province, China. We inoculated $6 \mathrm{~g}$ of sludge into $100 \mathrm{~mL}$ of potassium pyroantimonate solution with an $\mathrm{Sb}(\mathrm{V})$ concentration of $5 \mathrm{~g} / \mathrm{L}$ and incubated in $100 \mathrm{~mL}$ sealed anaerobic bottles at $37^{\circ} \mathrm{C}$ for 14 days. After incubation, $10 \mathrm{~mL}$ of sludge was 
then inoculated in the modified Postgate B medium [9] and incubated at $37^{\circ} \mathrm{C}$ for SRB enrichment with an $\mathrm{Sb}(\mathrm{V})$ concentration of $100 \mathrm{mg} / \mathrm{L}$ [7]. The SRB enriched cultures were then subcultured three times and used for isolation of SRB strains.

\subsection{Bacterial Community Analysis of SRB Enriched Culture by Illumina Sequencing of $16 S$ rRNA Genes}

The bacterial community structure of the SRB enriched culture was analyzed using high throughput sequencing of $16 \mathrm{~S}$ rDNA. The total DNA of the SRB enriched cultures were extracted using a E.Z.N.A. ${ }^{\circledR}$ Soil DNA Kit (Omega Bio-tek, Norcross, GA, USA), according to the manufacturer's protocols. Polymerase chain reaction(PCR) amplification of the V4-V5 region of the bacterial 16S rRNA gene was performed on GeneAmp 9700 PCR System (Applied Biosystems, Foster City, CA, USA) using primers 515F-907R. Sequencing and data analysis were carried out by Luojie Company (Luojie, Jinan, China).

\subsection{Isolation and Molecular Identification of Sb Tolerant SRB Strains}

The isolation of pure SRB strains by overlayer plate was conducted as reported previously [25] using the same medium with Fe (II) but no Sb(V) for enrichment. The black colonies on the plates were selected and sub cultured into fresh medium. This procedure was repeated three times until pure isolates were obtained. The purified SRB strains were then preserved at $-80^{\circ} \mathrm{C}$. At the end of the experiment, four pure cultures were obtained and analyzed.

The genomic DNA of all the SRB isolates and two SRB strains kindly provided by the Environmental Microbiology Experimental Group of Northwest University were extracted using TIANamp Bacteria DNA kits (Tiangen Biotech, Beijing, China) and following the manufacturer's instructions. The genomic DNA were examined using $0.7 \%$ agarose gel electrophoresis and used as templates for the amplification of 16S rRNA gene using bacterial universal primers $27 \mathrm{~F}$ and $1492 \mathrm{r}$. The SRB specific functional gene dsrB was also amplified using a primer pair of 2060F [26] and DSR4R [27]. The PCR settings for the two genes were used as reported previously [26]. The PCR products were examined by gel electrophoresis and sequenced by Sangon Biotech (Shanghai, China). The SRB isolate sequences were quality trimmed, and compared to reference sequences deposited in the GenBank database using the BLASTN algorithm (http: / / www.ncbi.nlm.nih.gov/BLAST/, accessed on 16 December 2021), and aligned using BioEdit (version 7.0.5, Manchester, UK). The phylogenetic trees were constructed using MEGA7 software (Mega Limited, Auckland, New Zealand) and the neighbor-joining approach, and the statistical support of hypotheses was assessed using 1000 bootstrap replicates [28].

\subsection{Sb(V) Removal by SRB Enrichment and Pure Culture of SRB from Synthetic Wastewater}

The synthetic wastewater was prepared by adding the necessary amount $(\mathrm{g})$ of potassium pyroantimonate solution to the modified Postgate B medium to reach a final $\mathrm{Sb}(\mathrm{V})$ concentration of $100 \mathrm{mg} / \mathrm{L}$. The composition of the medium was consistent with that used for enrichment except that ferrous sulfate was excluded. For the analysis of $\mathrm{Sb}$ removal activity of SRB enriched culture, the fresh culture was inoculated by $10 \%$ and added to synthetic wastewater and incubated in a sealed saline bottle at $37{ }^{\circ} \mathrm{C}$ for $48 \mathrm{~h}$. For the analysis of $\mathrm{Sb}$ removal activity of the purified SRB strains, SRB strains of $3 \times 10^{8} \mathrm{CFU} / \mathrm{mL}$ were inoculated into synthetic wastewater and incubated as described above. Samples were taken by syringe with a long needle at $0 \mathrm{~h}$ and $24 \mathrm{~h}$ for chemical analysis. To examine the Sb tolerance of SRB strains under higher Sb concentrations, the SRB strain 49 (named as SRB49) with the highest Sb removal efficiency among all six SRB strains was inoculated into synthetic wastewater with different initial $\mathrm{Sb}(\mathrm{V})$ concentrations of $100,200,300,400$, and $500 \mathrm{mg} / \mathrm{L}$ and were incubated at $37^{\circ} \mathrm{C}$ for $48 \mathrm{~h}$. Samples were taken at $0,5,12,24$, 30,36 , and $48 \mathrm{~h}$. All the batch experiments were conducted in triplicate. The data were presented as the mean values and standard deviations. 


\subsection{Effects of Different Culture Parameters on $S b(V)$ Removal by SRB Strain}

Batch experiments for $\mathrm{Sb}(\mathrm{V})$ removal under different culture parameters were conducted using the same procedure as described above. The batch experiments were performed in triplicate in $500 \mathrm{~mL}$ glass bottles sealed with rubber stoppers in an $\mathrm{Sb}(\mathrm{V})$ concentration of $100 \mathrm{mg} / \mathrm{L}$ and incubated at $37^{\circ} \mathrm{C}$ for $48 \mathrm{~h}$. At incubation times of $0,5,12,24,30$, 36 and $48 \mathrm{~h}, 10 \mathrm{~mL}$ of the culture aliquots were collected for chemical analysis.

To analyze effects of different initial redox potential on $\mathrm{Sb}(\mathrm{V})$ removal, different volumes of synthetic wastewater with an $\mathrm{Sb}(\mathrm{V})$ concentration of $100 \mathrm{mg} / \mathrm{L}$ was added to $500 \mathrm{~mL}$ glass bottles with an upper space of $0,20,40$, and $60 \mathrm{~mL}$. Another bottle filled with synthetic wastewater without upper space was further flushed with $\mathrm{N}_{2}$ for $15 \mathrm{~min}$ before autoclave and added $0.5 \mathrm{mg} / \mathrm{L}$ filter sterilized ascorbic acid before inoculation.

For effect analysis of temperature on $\mathrm{Sb}(\mathrm{V})$ removal, SRB49 strains were cultured at temperatures of $30,37,40$, and $45{ }^{\circ} \mathrm{C}$. For effect analysis of initial $\mathrm{pH}$ and sulfate concentration on $\mathrm{Sb}(\mathrm{V})$ removal, $\mathrm{SRB} 49$ strains were cultured at initial $\mathrm{pH}$ values of $6.5,7$, $7.2,7.5$, and 8 ; and sulfate concentrations of $0,4,8,16$, and $28 \mathrm{mM}$, respectively.

\subsection{Chemical Analysis and Statistical Analysis}

$\mathrm{Sb}$ concentration was determined by inductively coupled mass spectrometry (ICP-MS) using an Agilent 7900 ICP-MS (Tokyo, Japan). The liquid samples were taken from bottles using sterile syringes with long needles and filtered through the $0.22-\mu \mathrm{m}$ hydrophilic polyethersulfone (PES) membrane. The filtered samples were acidified with $\mathrm{HNO}_{3}$, diluted to ppb levels, and filtered again for ICP-MS analysis [29]. The concentration of sulfate was measured by barium chromate spectrophotometry [30]. The $\mathrm{pH}$ values and the redox potential were determined by $\mathrm{pH}$ meter (Sartorius PB-10, Gottingen, Germany) with and the REDOX potential meter (Leigi, PHS-3C, Shanghai, China). Statistical analysis to determine the significant difference $(p<0.05)$ was performed using GraphPad Prism software (version 6.0, San Diego, CA, USA) using a one way analysis of variance (ANOVA).

\subsection{SEM-EDX Analysis}

The precipitates formed after $48 \mathrm{~h}$ treatment of synthetic wastewater by SRB49 were analyzed by SEM-EDX [31]. The precipitates were washed twice with sterile phosphatebuffered saline (PBS), fixed with $2.5 \%$ glutaraldehyde, washed with PBS 3 times, dehydrated with ethanol at different gradients, and dried at room temperature for 2 days. Samples were sprayed with gold at $20 \mathrm{kV}, 128 \mu \mathrm{A}$ current, and characterized by scanning electron microscopy (SEM, Hitachis-3000N, Tokyo, Japan) operated at $15 \mathrm{kV}$ with a working distance of $10 \mathrm{~mm}$. For EDX (X-MAXN50) analysis, an accelerating voltage of $20 \mathrm{kV}$ was used to obtain sufficient $X$-ray counts.

\section{Conclusions}

In this study, high concentrations of $\mathrm{Sb}$ in simulated wastewater were removed by a pure culture of an $\mathrm{Sb}$ tolerant $\mathrm{SRB}$ strain that had been isolated from municipal sludge. Strain SRB49 was able to remove $95.7 \%$ of $\mathrm{Sb}(\mathrm{V})$ at a concentration of $100 \mathrm{mg} / \mathrm{L}$ within $48 \mathrm{~h}$ under optimum conditions: a temperature of $37-40^{\circ} \mathrm{C}$, an initial $\mathrm{pH}$ value of $8,4 \mathrm{mM}$ of sulfate, and an initial redox potential of $145-229 \mathrm{mV}$. This strain was identified as C. oxamicus. The mechanism of $\mathrm{Sb}$ removal by SRB49 was through metal sulfide precipitation with the formation of precipitate $\mathrm{Sb}_{2} \mathrm{~S}_{3}$, and no adsorption of $\mathrm{Sb}$ was observed on the surface of SRB49. The results demonstrated the roles of pure cultures of SRB species in Sb removal and highlighted the potential environmental importance of $\mathrm{Sb}$ tolerant SRB in Sb remediation. 


\begin{abstract}
Author Contributions: H.L. peroformed the experiments of isolation and molecular identification of of SRB strains, the batch experiments of Sb removal and SEM-EDX analysis; Y.F. carried out the molecular ecological analysis; G.Z., Z.B., S.X., S.Z., F.G., L.W., R.C. and Z.C. carried out the chemical analysis; G.Z. helped with data analysis and produced figures; J.Z. and H.L. wrote the manuscript; S.W. reviewed and edited the manuscript; J.Z. and S.W. designed and supervised the experiments. All authors have read and agreed to the published version of the manuscript.
\end{abstract}

Funding: This work was financially supported by National Natural Science Foundation of China (31300423 and 31770152), Natural Science Foundation of Shaanxi Province (2018JQ3022), Scientific Research Program Funded by Shaanxi Provincial Education Department (16JK1777), and National Key R\&D Program of China (2021YFC1808902).

Institutional Review Board Statement: Not applicable.

Informed Consent Statement: Not applicable.

Data Availability Statement: Not applicable.

Conflicts of Interest: The authors declare no conflict of interest.

\title{
References
}

1. He, M.; Wang, N.; Long, X.; Zhang, C.; Ma, C.; Zhong, Q.; Wang, A.; Wang, Y.; Pervaiz, A.; Shan, J. Antimony speciation in the environment: Recent advances in understanding the biogeochemical processes and ecological effects. J. Environ. Sci. (China) 2019, 75, 14-39. [CrossRef] [PubMed]

2. He, M.; Wang, X.; Wu, F.; Fu, Z. Antimony pollution in China. Sci. Total Environ. 2012, 421-422, 41-50. [CrossRef] [PubMed]

3. Ren, M.; Ding, S.; Fu, Z.; Yang, L.; Tang, W.; Tsang, D.C.W.; Wang, D.; Wang, Y. Seasonal antimony pollution caused by high mobility of antimony in sediments: In situ evidence and mechanical interpretation. J. Hazard. Mater. 2019, 367, 427-436. [CrossRef] [PubMed]

4. Nishad, P.A.; Bhaskarapillai, A. Antimony, a pollutant of emerging concern: A review on industrial sources and remediation technologies. Chemosphere 2021, 277, 130252. [CrossRef]

5. Sundar, S.; Chakravarty, J. Antimony toxicity. Int. J. Environ Res. Public Health 2010, 7, 4267-4277. [CrossRef] [PubMed]

6. Yamamura, S.; Iida, C.; Kobayashi, Y.; Watanabe, M.; Amachi, S. Production of two morphologically different antimony trioxides by a novel antimonate-reducing bacterium, Geobacter sp. SVR. J. Hazard. Mater. 2021, 411, 125100. [CrossRef] [PubMed]

7. Xi, Y.; Lan, S.; Li, X.; Wu, Y.; Yuan, X.; Zhang, C.; Yunguo, L.; Huang, Y.; Quan, B.; Wu, S. Bioremediation of antimony from wastewater by sulfate-reducing bacteria: Effect of the coexisting ferrous ion. Int. Biodeterior. Biodegrad. 2020, $148,104912$. [CrossRef]

8. Zhu, Y.; Wu, M.; Gao, N.; Chu, W.; An, N.; Wang, Q.; Wang, S. Removal of antimonate from wastewater by dissimilatory bacterial reduction: Role of the coexisting sulfate. J. Hazard. Mater. 2018, 341, 36-45. [CrossRef]

9. Wang, H.; Chen, F.; Mu, S.; Zhang, D.; Pan, X.; Lee, D.-J.; Chang, J.-S. Removal of antimony (Sb (V)) from Sb mine drainage: Biological sulfate reduction and sulfide oxidation-precipitation. Bioresour. Technol. 2013, 146, 799-802. [CrossRef]

10. Kulp, T.R.; Miller, L.G.; Braiotta, F.; Webb, S.M.; Kocar, B.D.; Blum, J.S.; Oremland, R.S. Microbiological Reduction of Sb(V) in Anoxic Freshwater Sediments. Environ. Sci. Technol. 2014, 48, 218-226. [CrossRef]

11. Li, Y.C.; Xu, Z.; Wu, J.X.; Mo, P. Efficiency and mechanisms of antimony removal from wastewater using mixed cultures of iron-oxidizing bacteria and sulfate-reducing bacteria based on scrap iron. Sep. Purif. Technol. 2020, 246, 116756. [CrossRef]

12. Wang, L.; Ye, L.; Yu, Y.; Jing, C. Antimony Redox Biotransformation in the Subsurface: Effect of Indigenous Sb(V) Respiring Microbiota. Environ. Sci. Technol. 2018, 52, 1200-1207. [CrossRef] [PubMed]

13. Zhang, G.; Ouyang, X.; Li, H.; Fu, Z.; Chen, J. Bioremoval of antimony from contaminated waters by a mixed batch culture of sulfate-reducing bacteria. Int. Biodeterior. Biodegrad. 2016, 115, 148-155. [CrossRef]

14. Xiao, E.Z.; Krumins, V.; Tang, S.; Xiao, T.F.; Ning, Z.P.; Lan, X.L.; Sun, W.M. Correlating microbial community profiles with geochemical conditions in a watershed heavily contaminated by an antimony tailing pond. Environ. Pollut. 2016, 215, 141-153. [CrossRef] [PubMed]

15. Baek, Y.-W.; An, Y.-J. Microbial toxicity of metal oxide nanoparticles $\left(\mathrm{CuO}, \mathrm{NiO}, \mathrm{ZnO}\right.$, and $\left.\mathrm{Sb}_{2} \mathrm{O}_{3}\right)$ to Escherichia coli, Bacillus subtilis, and Streptococcus aureus. Sci. Total Environ. 2011, 409, 1603-1608. [CrossRef] [PubMed]

16. Ye, L.; Chen, H.; Jing, C. Sulfate-Reducing Bacteria Mobilize Adsorbed Antimonate by Thioantimonate Formation. Environ. Sci. Technol. Lett. 2019, 6, 418-422. [CrossRef]

17. Liu, F.; Zhang, G.; Liu, S.; Fu, Z.; Chen, J.; Ma, C. Bioremoval of arsenic and antimony from wastewater by a mixed culture of sulfate-reducing bacteria using lactate and ethanol as carbon sources. Int. Biodeterior. Biodegrad. 2018, 126, 152-159. [CrossRef]

18. Abin, C.A.; Hollibaugh, J.T. Desulfuribacillus stibiiarsenatis sp. nov., an obligately anaerobic, dissimilatory antimonate- and arsenate-reducing bacterium isolated from anoxic sediments, and emended description of the genus Desulfuribacillus. Int. J. Syst. Evol. Microbiol. 2017, 67, 1011-1017. [CrossRef] 
19. Lai, C.Y.; Wen, L.L.; Zhang, Y.; Luo, S.S.; Wang, Q.Y.; Luo, Y.H.; Chen, R.; Yang, X.E.; Rittmann, B.E.; Zhao, H.P. Autotrophic antimonate bio-reduction using hydrogen as the electron donor. Water Res. 2016, 88, 467-474. [CrossRef]

20. Muyzer, G.; Stams, A.J.M. The ecology and biotechnology of sulphate-reducing bacteria. Nat. Rev. Microbiol. 2008, 6, 441-454. [CrossRef]

21. Li, X.; Xiao, H.; Zhang, W.; Li, Y.; Tang, X.; Duan, J.; Yang, Z.; Wang, J.; Guan, F.; Ding, G. Analysis of cultivable aerobic bacterial community composition and screening for facultative sulfate-reducing bacteria in marine corrosive steel. J. Oceanol. Limnol. 2019, 37, 600-614. [CrossRef]

22. Chen, W.; Xiang, F.; Fu, J.; Wang, Q.; Wang, W.; Zeng, Q.; Yu, L. Identification and Phylogenetic Analysis of New Sulfate-Reducing Bacteria Isolated from Oilfield Samples. Z. Nat. C 2009, 64, 260-266. [CrossRef] [PubMed]

23. Mogensen, G.L.; Kjeldsen, K.U.; Ingvorsen, K. Desulfovibrio aerotolerans sp nov., an oxygen tolerant sulphatereducing bacterium isolated from activated sludge. Anaerobe 2005, 11, 339-349. [CrossRef] [PubMed]

24. Okkenhaug, G.; Zhu, Y.-G.; He, J.; Li, X.; Luo, L.; Mulder, J. Antimony (Sb) and Arsenic (As) in Sb Mining Impacted Paddy Soil from Xikuangshan, China: Differences in Mechanisms Controlling Soil Sequestration and Uptake in Rice. Environ. Sci. Technol. 2012, 46, 3155-3162. [CrossRef]

25. Ňancucheo, I.; Rowe, O.F.; Hedrich, S.; Johnson, D.B. Solid and liquid media for isolating and cultivating acidophilic and acid-tolerant sulfate-reducing bacteria. FEMS Microbiol. Lett. 2016, 363, fnw083. [CrossRef]

26. Geets, J.; Borrernans, B.; Diels, L.; Springael, D.; Vangronsveld, J.; van der Lelie, D.; Vanbroekhoven, K. DsrB gene-based DGGE for community and diversity surveys of sulfate-reducing bacteria. J. Microbiol. Methods 2006, 66, 194-205. [CrossRef]

27. Wagner, M.; Roger, A.J.; Flax, J.L.; Brusseau, G.A.; Stahl, D.A. Phylogeny of dissimilatory sulfite reductases supports an early origin of sulfate respiration. J. Bacteriol. 1998, 180, 2975-2982. [CrossRef]

28. Zhang, J.; Wu, S.S.; Zhao, L.H.; Ma, Q.L.; Li, X.; Ni, M.Y.; Zhou, T.; Zhu, H.L. Culture-dependent and-independent analysis of bacterial community structure in Jiangshui, a traditional Chinese fermented vegetable food. LWT-Food Sci. Technol. 2018, 96, 244-250.

29. Althobiti, R.A.; Beauchemin, D. Pragmatic method based on on-line leaching and inductively coupled plasma mass spectrometry for risk assessment of the impact of short-term pollution. J. Anal. At. Spectrom. 2021, 36, 622-629. [CrossRef]

30. Kolmert, A.; Wikstrom, P.; Hallberg, K.B. A fast and simple turbidimetric method for the determination of sulfate in sulfatereducing bacterial cultures. J. Microbiol. Methods 2000, 41, 179-184. [CrossRef]

31. Castillo, U.; Myers, S.; Browne, L.; Strobel, G.; Hess, W.M.; Hanks, J.; Reay, D. Scanning electron microscopy of some endophytic streptomycetes in Snakevine-Kennedia nigricans. Scanning 2005, 27, 305-311. [CrossRef] [PubMed] 